\title{
FORMATION OF STREPTOMYCES PROTOPLASTS DURING CULTIVATION IN LIQUID MEDIA WITH LYTIC ENZYME
}

\author{
ZUZANA BRNÁKOVÁ ${ }^{1}$, JARMILA FARKAŠOVSKÁ ${ }^{1}$, \\ ANNAMÁRIA RUSNÁKOVÁ ${ }^{1}$, ANDREJ GODÁNY ${ }^{1,2}$ \\ ${ }^{1}$ Institute of Molecular Biology, Slovak Academy of Sciences, Dúbravská cesta 21, \\ SK-845 51 Bratislava, Slovak Republic, (zuzana.brnakova@savba.sk) \\ ${ }^{2}$ Department of Biotechnology, University of SS. Cyril and Methodius, J. Herdu 2, \\ Trnava, SK-917 01, Slovak Republic
}

\begin{abstract}
Many streptomycetes strains are hardly or not at all transformable via protoplasts, or there is a problem with the regeneration of protoplasts. We found that protoplasts are formed directly in cultivation media under submerged conditions in the presence of lytic enzyme. Actinophage $\mu 1 / 6$ endolysin and lysozyme were used in this study. Streptomyces strains were cultivated in several media with glycine and lytic enzyme for 24 and $48 \mathrm{~h}$. The highest amounts of protoplasts (about $3 \times 10^{7} \mathrm{cfu} / \mathrm{ml}$ of cultivation medium) together with the highest regeneration $(95 \%)$ and transformation frequency (about $2 \times 10^{6}-10^{7}$ $\mathrm{cfu} / \mu \mathrm{g}$ DNA) were obtained reproducibly in YEME medium with high sucrose content. S. aureofaciens B96, as hardly transformable strain because of difficulties with protoplast preparation and their further regeneration, was used in this study. The same procedure was applied to S. lividans 66 TK24 and S. coelicolor A3(2), streptomycetes model strains, to confirm the general use of this method. Moreover, such cultivation process was appropriate for additional quick isolation of either chromosomal as well as plasmid DNA that could be further used in recombinant DNA techniques.
\end{abstract}

Keywords: Streptomyces, protoplasts, transformation, lysozyme, actinophage $\mu 1 / 6$ endolysin

\section{Introduction}

Streptomyces are unusual among bacteria in growing as mycelial colonies with sporulating aerial hyphae. They are known for degradation of numerous macromolecules and synthesis of a wide range of antibiotics and other commercially important secondary metabolites. The complex life cycle of these bacteria includes formation of substrate mycelia, aerial hyphae and spores (PIGAC and SCHREMPF 1995). The study of the genetics of Streptomyces is important not only because of many antibiotics, but also because its differentiation and its regulation of secondary metabolism are of basic interest (OCHI 1982). The preparation and regeneration of protoplasts are major steps following genetic manipulations such as fusion, transfection and transformation of Streptomyces species.

Despite there have been reports of "natural" transformation and transfection of Streptomyces cultures, there is no such system generally applicable to most species (KIESER et al. 2000). Besides transfection and transformation, there have been further means of plasmid transfer described. Intergeneric conjugation, using Escherichia coli as a donor, allows constructing and manipulating recombinant plasmids in E. coli and subsequently transferring them into Streptomyces (PARANTHAMAN and 
DHARMALINGAM 2003; HOU et al. 2008). Further alternative to using chemicals for promoting an uptake of DNA by cells is electroporation. Protoplasts of $S$. venezuelae and some other streptomycetes, formerly not transformable by the standard protocol, were successfully transformed by electroporation (PIGAC and SCHREMPF 1995). In addition, protoplast fusion is widely used for genome shuffling among interspecies and intergenetic microorganisms (IMADA et al. 2002; EL-GENDY et al. 2008; XU et al. 2008).

Though, the most of aforementioned methods require preparation of protoplasts and their successful regeneration. It has been found that the regeneration frequency of the protoplasts varies according to the species used and high regeneration frequency is limited to a narrow range of Streptomyces species (SHIRAHAMA et al. 1981, IMADA et al. 2002). For the further study of genes in various Streptomyces it was necessary to develop procedures for efficient protoplast regeneration and plasmid transformation remembering also the potential presence of the restriction-modification system (MATSUSHIMA and BALTZ 1985; MATSUSHIMA et al. 1987; GODÁNY et al. 1991; MUCHOVÁ et al. 1991).

The aim of this study was to try the effect of lytic enzymes, mainly actinophage $\mu 1 / 6$ endolysin, on protoplast preparation during cultivation under submerged conditions. Up to now, this kind of procedure has not been reported. This work describes an easy and effective method for preparation of protoplasts from Streptomyces species, mainly Streptomyces aureofaciens B96, by cultivation in liquid medium containing lysozyme or actinophage $\mu 1 / 6$ endolysin. Furthermore, cultivation with lytic enzyme facilitates the isolation of chromosomal and plasmid DNA.

\section{Materials and methods}

\subsection{Bacterial strains and plasmids}

Streptomyces strains used in this study: S. aureofaciens B96 (Collection of Microorganisms, Institute of Molecular Biology SAS Bratislava); S. coelicolor A3(2), and S. lividans 66 TK24 (HOPWOOD et al. 1985). Shuttle promoter-probe vector pKJ2 (NAZAROV et al. 1990) was used as a control for transformation of protoplasts.

\subsection{Culture conditions and solutions}

Streptomyces sp. were cultivated in TSB (tryptone soya broth powder, Oxoid; containing $0.7 \%$ glycine), TSSB (TSB $+10.3 \%$ sucrose, $0.7 \%$ glycine, Serva), NB (nutrient broth No. 2, Imuna Šarišské Michal'any; containing 0.7\% glycine), NBS (NB $+10.3 \%$ sucrose and $0.7 \%$ glycine), YEME (prepared according to KIESER et al. 2000, containing 0.7\% glycine), sterile P buffer (prepared according to KIESER et al. 2000) and 25\% PEG 1000 in T buffer (prepared according to KIESER et al. 2000), lysozyme water solution (Applichem, $40 \mathrm{mg} / \mathrm{ml}$, filter sterilized), actinophage $\mu 1 / 6$ endolysin (FARKAŠOVSKÁ et al. 2003, $5 \mathrm{mg} / \mathrm{ml}$ ), appropriately dried plates No. $16 \mathrm{M}\left(10.3 \%\right.$ sucrose, $1.5 \%$ dextrin, $0.001 \%$ urea, $0.005 \% \mathrm{NaCl}, 0.005 \% \mathrm{~K}_{2} \mathrm{HPO}_{4}$, 
$0.005 \% \mathrm{MgSO}_{4}, 0.5 \%$ peptone, $0.1 \%$ beef extract, $2 \mathrm{ml} / 1$ trace element solution (KIESER et al. 2000) and 3\% agar, $\mathrm{pH}$ 7.2).

Solutions used further in this study: thiostrepton (Calbiochem, $50 \mathrm{mg} / \mathrm{ml}$ in DMSO), TE buffer (10mM Tris-HCl, $\mathrm{pH} 8,1 \mathrm{mM}$ EDTA), neutral phenol-chloroform (1:1, equilibrated with TE buffer, $\mathrm{pH} 8)$, acid phenol-chloroform (1:1, equilibrated with water), $3 \mathrm{M}$ sodium acetate $\mathrm{pH} 4.8$.

\subsection{Growth of Streptomyces mycelium for protoplasts preparation}

$10 \mathrm{ml}$ of sterile media containing lysozyme (SERVA, final concentration $1 \mathrm{mg} / \mathrm{ml}$ and $2 \mathrm{mg} / \mathrm{ml}$, respectively) or actinophage $\mu 1 / 6$ endolysin (final concentration $0.15 \mathrm{mg} / \mathrm{ml}$ and $0.3 \mathrm{mg} / \mathrm{ml}$, respectively) in $100 \mathrm{ml}$ Erlenmeyer flasks were inoculated with $200 \mu \mathrm{l}$ of dense spore suspension (prepared according to KIESER et al. 2000). The lytic enzyme (lysozyme or endolysin) was added either immediately with inoculum or after $8 \mathrm{~h}$ of incubation. Flasks were incubated at $30^{\circ} \mathrm{C}$ on rotary shaker for 24 and 48 hours while testing the suitable medium for protoplast preparation.

In the next step, $10 \mathrm{ml}$ of TSB with glycine, but without lytic enzyme, was inoculated with $1 \mathrm{ml}$ of dense spore suspension. The flasks were incubated at $30^{\circ} \mathrm{C}$ on rotary shaker for $20-24$ hours. After that, $1 \times 10^{6}$ of colony forming units (cfu) were used as inoculum to $25 \mathrm{ml}$ of YEME medium with lytic enzyme (apart from the control flask) and incubated for 24 and 48 hours.

The culture medium was poured into screw cap bottle and centrifuged. The supernatant was discarded and the pellet was suspended in $10 \mathrm{ml}$ of $\mathrm{P}$ buffer. Suspension was filtered through cotton wool (using a filter tube) and transferred into a plastic tube. The protoplasts were collected by centrifugation at $2800 \mathrm{rpm}$. Pellet was resuspended in $500 \mu l$ of $\mathrm{P}$ buffer.

\subsection{Transformation of protoplasts}

Transformation of protoplasts with pKJ2 plasmid DNA was done according to HOPWOOD et al. (1985) rapid small-scale procedure and plated on 16M agar plates (regeneration medium, $10.3 \%$ sucrose, $1.5 \%$ dextrin, $0.001 \%$ urea, $0.005 \% \mathrm{NaCl}$, $0.005 \% \mathrm{~K}_{2} \mathrm{HPO}_{4}, 0.005 \% \mathrm{MgSO}_{4}, 0.5 \%$ peptone, $0.1 \%$ beef extract, $2 \mathrm{ml} / 1$ of trace element solution (HOPWOOD et al. 1985) and 3\% agar, $\mathrm{pH} 7.2$ ). After $20 \mathrm{~h}$ incubation at $30^{\circ} \mathrm{C}$ the agar plates were overlaid with $1 \mathrm{ml}$ of thiostrepton $(300 \mu \mathrm{g} / \mathrm{ml}$ water solution), dried and incubated at $30^{\circ} \mathrm{C}$ for $2-3$ days.

\subsection{Isolation of Streptomyces “total” DNA}

$1 \mathrm{ml}$ of medium after 24 and $48 \mathrm{~h}$ incubation was centrifuged and neutral phenolchloroform was added to supernatant. The extraction from phenol-chloroform was repeated until the white interface was seen. The DNA was precipitated from supernatant by adding $1 / 10$ volume of $3 \mathrm{M}$ sodium acetate and 1 volume of isopropanol. After incubation at room temperature and centrifugation, the pellet was 
washed by $96 \%$ ethanol and dried slightly. Then, the pellet was dissolved in $50 \mu \mathrm{l}$ of TE buffer and the presence of isolated DNA was confirmed by $0.9 \%$ agarose gel electrophoresis using ethidium bromide detection.

\subsection{Isolation of plasmid DNA}

For this part of work, pKJ2 transformants of $S$. aureofaciens, S. lividans and $S$. coelicolor were used as inoculum. $1 \mathrm{ml}$ of culture medium after 24 and $48 \mathrm{~h}$ incubation was centrifuged and acid phenol-chloroform was added to supernatant. Mixture was vortex mixed and centrifuged. The supernatant was removed, leaving the white interface behind. $1 / 10$ volume of $3 \mathrm{M}$ unbuffered sodium acetate and 2 volumes of $96 \%$ ethanol was added to supernatant and mixed. Mixture was incubated at $-20^{\circ} \mathrm{C}$ and then centrifuged. The pellet was dissolved in $500 \mu$ l of TE buffer and the solution was extracted by neutral phenol-chloroform until no white interface was seen. 1/10 volume of $3 \mathrm{M}$ unbuffered sodium acetate and 2 volumes of $96 \%$ ethanol was added to supernatant and mixed. Mixture was incubated at $-20^{\circ} \mathrm{C}$ and then span. The pellet was dissolved in $25 \mu \mathrm{l}$ of TE buffer, visualized in $0.9 \%$ agarose gel electrophoresis using ethidium bromide detection and $5 \mu$ of such solution was used for transformation into protoplasts.

\section{Results and discussion}

\subsection{Protoplasts preparation}

Polyethylene glycol (PEG)-mediated plasmid transformation of protoplasts had allowed the rapid development of gene cloning in various Streptomyces species, particularly in S. lividans 66, S. ambofaciens, S. coelicolor A3(2), S. fradiae, and S. rimosus, as well as in some others (PIGAC and SCHREMPF, 1995). This transformation procedure has been generally applicable to several Streptomyces species, although it has been necessary to optimize growth and establish the optimal conditions for protoplast formation and regeneration. Moreover, the transformation of the fragile protoplasts has been tedious and frequently not reproducible; thus, numerous Streptomyces strains could not be proven to be transformable.

Preparation of protoplasts is essential for further genetic manipulations, such as transformation, transfection (KIESER et al. 2000), electroporation (PIGAC and SCHREMPF, 1995) or protoplast fusion (XU et al. 2008), known so far. Furthermore, there has been considerable interest in the use of the intergeneric conjugation as a means of plasmid transfer, using E. coli as a donor (VOEYKOVA et al. 1998; HOU et al. 2008).

Despite all possibilities, transformation stayed the most applied method, and many problems with transformation and protoplast regeneration of Streptomyces species still preserved. Strain development and genetic analysis of several important streptomycetes has been hindered by the apparent lack of natural fertility, the lack of transduction or transformation, and by restriction-modification systems. Restriction endonuclease activities, having role in the protection of the bacterial genome, can 
complicate genetic manipulation of the bacterium by affecting transformation efficiency and stability of recombinant DNA (APICHAISATAIENCHOTE et al. 2005). Several methods have been designed in an attempt to improve protoplasts preparation and regeneration in Streptomyces, including glycine treatment of mycelia, use of mixture of lytic enzymes, and supplementation of metal ions and osmotic stabilizers (YANG and LEI, 2001). Our studies showed that cells could be transformed at a high frequency when the recipient Streptomycetes protoplasts are formed by treatment with lytic enzyme during the cultivation.

In this work, S. aureofaciens B96, hardly transformable Streptomyces strain, and model strains, S. coelicolor and S. lividans, were used for setting the conditions for protoplast preparation during the cultivation process. Streptomyces under submerged conditions enter the log phase before $24 \mathrm{~h}$, stationary phase between 24 and $96 \mathrm{~h}$, and declining phase after $96 \mathrm{~h}$ of incubation. It was reported that Streptomyces protoplast formation was high in the early stationary phase and decreased in the late stationary phase (KIESER et al. 2000; YANG and LEI, 2001). In addition, protoplast formation also increased in the decline phase, likely due to the autolysis of mycelia and partial damage of the cell wall. RODICIO et al. (1978) found that protoplasts were yielded in young mycelia treated with lysozyme, even when the glycine was not added during the growth period. However, protoplast formation in old mycelia required the presence of glycine during the cultivation. Therefore, mycelium grown at the late log to the middle stationary phase treated with lysozyme was effective for protoplast preparation. In our study, glycine was used in all media as a factor increasing susceptibility to the action of agents degrading the cell wall. S. aureofaciens was cultivated in various media with addition of lytic enzyme. The numbers of formed protoplasts, counted in Bürker counting chamber, are shown in Tables 1 and 2.

Table1. Effect of lytic enzymes on number of S. aureofaciens B96 protoplasts in various media. Lytic enzymes were added to media after $8 \mathrm{~h}$ of incubation. Protoplast concentration is in $\mathrm{cfu} / \mathrm{ml}$ of medium.

\begin{tabular}{ccccccccc}
\hline \multirow{2}{*}{ Medium } & \multicolumn{4}{c}{ Lysozyme } & \multicolumn{4}{c}{ Endolysin } \\
& \multicolumn{2}{c}{$1 \mathrm{mg} / \mathrm{ml}$} & $2 \mathrm{mg} / \mathrm{ml}$ & $0.15 \mathrm{mg} / \mathrm{ml}$ & $0.3 \mathrm{mg} / \mathrm{ml}$ \\
\cline { 2 - 9 } & $24 \mathrm{~h}$ & $48 \mathrm{~h}$ & $24 \mathrm{~h}$ & $48 \mathrm{~h}$ & $24 \mathrm{~h}$ & $48 \mathrm{~h}$ & $24 \mathrm{~h}$ & $48 \mathrm{~h}$ \\
\hline NB + gly & -- & -- & -- & -- & -- & -- & -- & -- \\
NBS + gly & $2 \times 10^{6}$ & $2 \times 10^{6}$ & -- & -- & $4 \times 10^{6}$ & $4 \times 10^{6}$ & $4 \times 10^{6}$ & $4 \times 10^{6}$ \\
TSB + gly & $4 \times 10^{6}$ & $2 \times 10^{6}$ & $4 \times 10^{6}$ & $2 \times 10^{6}$ & $8 \times 10^{6}$ & $8 \times 10^{6}$ & $8 \times 10^{6}$ & $8 \times 10^{6}$ \\
TSSB + gly & $12 \times 10^{6}$ & $8 \times 10^{6}$ & $14 \times 10^{7}$ & $12 \times 10^{6}$ & $16 \times 10^{7}$ & $14 \times 10^{6}$ & $16 \times 10^{6}$ & $14 \times 10^{6}$ \\
\hline
\end{tabular}

There were too few protoplasts formed, when the lytic enzyme was added immediately into the cultivation media (less than $100 \mathrm{cfu} / \mathrm{ml}$ ). More effectual results were when the lytic enzymes were added after $8 \mathrm{~h}$ incubation of Streptomyces culture (Table $1 ; 2 \times 10^{6}-1 \times 10^{7} \mathrm{cfu} / \mathrm{ml}$ ). Under these conditions, the best results were acquired in TSSB medium $\left(12-14 \times 10^{6} \mathrm{cfu} / \mathrm{ml}\right)$, where additional sucrose was added to form hypertonic environment. Moreover, if NB and NBS media were compared, there were no protoplasts observed in media without any osmotic stabilizer. However, the formation of protoplasts was influenced by the composition of cultivation media. NB 
is a complex cultivation medium and was not suitable for Streptomyces aureofaciens. Optimal protoplast formation was obtained by treatment of mycelium with lytic enzyme during cultivation in YEME medium (1000mM sucrose, Table 2). However, S. aureofaciens grew with much difficulties in such hypertonic medium and needed to be pre-cultivated overnight in TSB medium, where its growth was very extensive.

Table 2. Effect of lytic enzymes on number of S. aureofaciens B96 protoplasts in YEME medium. The inoculum was $20-24 \mathrm{~h}$ fresh culture pre-cultivated in TSB+gly medium. Protoplast concentration is in cfu/ml of medium.

\begin{tabular}{ccccc}
\hline Time of & \multicolumn{2}{c}{ Lysozyme } & \multicolumn{2}{c}{ Endolysin } \\
cultivation & $1 \mathrm{mg} / \mathrm{ml}$ & $2 \mathrm{mg} / \mathrm{ml}$ & $0.15 \mathrm{mg} / \mathrm{ml}$ & $0.3 \mathrm{mg} / \mathrm{ml}$ \\
\hline $24 \mathrm{~h}$ & $24 \times 10^{6}$ & $26 \times 10^{6}$ & $29 \times 10^{6}$ & $30 \times 10^{6}$ \\
$48 \mathrm{~h}$ & $26 \times 10^{6}$ & $29 \times 10^{6}$ & $31 \times 10^{6}$ & $31 \times 10^{6}$ \\
\hline
\end{tabular}

The concentrations of lytic enzymes were selected according to preliminary studies in our laboratory and related to lysozyme they were consistent with the results of KIESER et al. (2000) standard protocols for protoplast preparation. Mycelium was grown in YEME medium with glycine for 48 hours. For comparison, protoplasts were prepared also by procedure described in KIESER et al. (2000) with $1 \mathrm{mg} / \mathrm{ml}$ of lysozyme for $S$. lividans or $S$. coelicolor and $2 \mathrm{mg} / \mathrm{ml}$ of lysozyme $S$. aureofaciens (Table 2), respectively. The amounts of prepared protoplasts were comparable to those formed by cultivation directly with lytic enzyme in YEME medium (approximately $50 \times 10^{7} \mathrm{cfu} / \mathrm{ml}$ in the case of S. lividans or S. coelicolor, and $30 \times 10^{7} \mathrm{cfu} / \mathrm{ml}$ in the case of $S$. aureofaciens). The reproducible results from liquid cultivation with lytic enzymes are summarized in Tables 2 and 3. There was not a significant difference among the final protoplast amounts, when the different concentrations of lytic enzyme were used directly in media during the cultivation process. In this study, even the lower concentration $(1 \mathrm{mg} / \mathrm{ml}$ of lysozyme and $0.15 \mathrm{mg} / \mathrm{ml}$ of actinophage endolysin) was enough for protoplast formation.

Table 3. Effect of lytic enzymes on number of S. lividans 66 TK24 and S. coelicolor A3(2) protoplasts in YEME medium. Protoplast concentration is in $\mathrm{cfu} / \mathrm{ml}$ of medium.

\begin{tabular}{ccccc}
\hline Time of & \multicolumn{2}{c}{ lysozyme $(2 \mathrm{mg} / \mathrm{ml})$} & \multicolumn{2}{c}{ endolysin $(0.3 \mathrm{mg} / \mathrm{ml})$} \\
\cline { 2 - 5 } cultivation & S. lividans & S. coelicolor & S. lividans & S. coelicolor \\
\hline $24 \mathrm{~h}$ & $48 \times 10^{6}$ & $45 \times 10^{6}$ & $50 \times 10^{6}$ & $51 \times 10^{6}$ \\
$48 \mathrm{~h}$ & $50 \times 10^{6}$ & $49 \times 10^{6}$ & $51 \times 10^{6}$ & $51 \times 10^{6}$ \\
\hline
\end{tabular}

Following the cultivation, protoplasts were centrifuged, washed by P-buffer and filtrated to remove possible mycelia. The important fact was not to dilute cultivation medium because of osmotic instability of protoplasts. After centrifugal concentration at $2800 \mathrm{rpm}$, protoplasts were ready for transformation. In this state, acquired amounts of $S$. aureofaciens protoplasts were $25 \times 10^{9} / \mathrm{ml}$ and $25 \times 10^{10} / \mathrm{ml}, 5 \times 10^{10} / \mathrm{ml}$ and $4 \times 10^{11} / \mathrm{ml}$ in the case of $1 \mathrm{mg} / \mathrm{ml}$ and $2 \mathrm{mg} / \mathrm{ml}$ of lysozyme; $0.25 \mathrm{mg} / \mathrm{ml}$ and $0.5 \mathrm{mg} / \mathrm{ml}$ of endolysin used, respectively.

Protoplast regeneration frequency is estimated by the ratio of cell number to protoplast number. It was reported before, that the cell regeneration from protoplasts 
of Streptomyces depended on the medium components, age of mycelia, dehydratation of plates and culture temperature. It was also found that the presence of non-protoplast mycelium fragments could affect the cellular regeneration from protoplasts (YANG and LEI, 2001). Regeneration medium, No. 16M was suitable for all Streptomyces strains tested in this study, and protoplasts were regenerated after 2-3 days of incubation at $30^{\circ} \mathrm{C}$. The regeneration frequencies were about $95 \%$ for S. aureofaciens, $94.3 \%$ and $94 \%$ for S. lividans and S. coelicolor, respectively. But in general, because of the diversity of Streptomyces, the composition of the regeneration media has to be optimized for each strain.

\subsection{Transformation of protoplasts}

In past years, polyethylene glycol (PEG)-mediated plasmid transformation of protoplasts had allowed the rapid development of gene cloning in various Streptomyces species. Although this transformation procedure is generally applicable to several Streptomyces species, it is necessary to optimize growth and establish the optimal conditions for protoplast formation and regeneration. Moreover, the transformation of the fragile protoplasts is tedious and frequently not reproducible; thus, numerous Streptomyces strains could not be proven to be transformable (MELLOULI et al. 2004).

PEG induces plasmid transformation in Streptomyces species apparently by interacting with cytoplasmic membrane structure, thus allowing plasmid DNA uptake (GARCIA-DOMINGUEZ et al. 1987). Protoplasts of S. aureofaciens B96, in this study, were transformed by pKJ2 plasmid DNA. Thiostrepton resistance marker is well expressed in S. aureofaciens and suggested good selection of transformants based on the resistance to this antibiotic. When the protoplasts of $S$. aureofaciens were prepared following the method developed for S. lividans and S. coelicolor by HOPWOOD et al. (1985), the extremely low initial transformation frequency with plasmid DNA was observed (less than 100 transformants per $\mu \mathrm{g}$ DNA). Despite, the frequencies in S. lividans and S. coelicolor were between $10^{6}-10^{7} \mathrm{cfu} / \mu \mathrm{g}$ of plasmid DNA. Alike in the case of media without or with $300 \mathrm{mM}$ sucrose, there was only little transformation frequency with plasmid DNA (5-10\%). The highest transformation efficiency was observed when S. aureofaciens was cultivated with lytic enzyme in YEME medium (1000mM sucrose, pre-cultivated in TSB medium with glycine). Protoplast numbers after concentration were $25 \times 10^{9} \mathrm{cfu} / \mathrm{ml}$ and $25 \times 10^{10} \mathrm{cfu} / \mathrm{ml}$ in the case of $1 \mathrm{mg} / \mathrm{ml}$ and $2 \mathrm{mg} / \mathrm{ml}$ of lysozyme; $5 \times 10^{10} / \mathrm{ml}$ and $4 \times 10^{11} / \mathrm{ml}$ when $0.25 \mathrm{mg} / \mathrm{ml}$ and $0.5 \mathrm{mg} / \mathrm{ml}$ of endolysin was used, respectively. Not only the best results in protoplast formation were in such osmotic medium, but also the regeneration of the protoplasts was more than $95 \%$ and the transformation frequency was comparable to $S$. lividans and $S$. coelicolor used in this study (in all cases the transformation frequencies were reproducibly about $2 \times 10^{6}-10^{7} \mathrm{cfu} / \mu \mathrm{g}$ DNA). These results corresponded to the results published previously for S. lividans and S. coelicolor (KIESER et al. 2000) and the other Streptomyces strains (SHIRAHAMA et al. 1981; MATSUSHIMA and BALTZ 1985; and more). There was an irrelevant difference in transformation frequency regarding to concentrations of lytic enzymes used in cultivation media and 
the type of plasmid. Neither the size nor the origin of the plasmid DNA played the role in this study. The preliminary studies in our lab showed that transformation frequency did not depend on the size of the cloning vector (data not shown). Despite $S$. aureofaciens B96 protoplasts were stable after storing at $-70^{\circ} \mathrm{C}$ under any condition used, they were not transformable any more. They always had to be prepared fresh. Opposite, S. lividans and S. coelicolor protoplasts, prepared in the same way as aforementioned $S$. aureofaciens, were stable at $-70^{\circ} \mathrm{C}$ in $\mathrm{P}$ buffer for at least six months.

\subsection{Isolation of "total” and plasmid DNA}

There are various procedures of Streptomyces DNA isolation (KIESER et al. 2000). In general, the first step for DNA isolation is the lysis of the cell walls. They require treatment with SDS or sarkosyl, then incubation with lysozyme at $30^{\circ}$ or $37^{\circ} \mathrm{C}$ with periodical trituration. This step takes usually long time and sometimes not all of the mycelia are lysed. Furthermore, the regeneration and transformation ability of protoplasts depends on the way of preparation in many cases. All DNA isolation methods in this study were simplified procedures according to KIESER et al. (2000). They were not such time-consuming, as the step of cell wall lysis was excluded. Visually, except for the YEME with high sucrose content, all media were viscous after cultivation with lytic enzyme. There were only a few protoplasts after cultivation in these media, so we assumed that the most of them broke and intracellular content with DNA split into the medium. After that, no lysis was needed and the whole isolation was based only on extraction from phenol, phenol-chloroform and on alcohol precipitation. If hypertonic medium was used for cultivation, like YEME, it was better to dilute the medium either with water or $10.3 \%$ sucrose to let the protoplasts break and split inner content into the medium.

It was also possible to isolate plasmid DNA from such cultivation media. The only difference was the extraction from acid phenol-chloroform at first. Consequently, the plasmid DNAs were purified like total DNA. Plasmid DNAs isolated by this procedure were able to transform repeatedly into Streptomyces protoplasts.

According to one's needs, by addition of the lytic enzyme into medium during cultivation it is possible to acquire protoplasts with high regeneration and transformation frequency or isolate chromosomal and plasmid DNA. This procedure is applicable to protoplast preparation from many Streptomyces species, even from hardly transformable industrial strains, when high concentration of sucrose, as osmotic stabilizer is added into liquid medium. This method is easier, more effective and not so time-consuming than developing and optimizing new procedures. Additionally, chromosomal DNA and plasmid DNA isolations are very easy and quick, as the cell lysis step is excluded.

\section{Acknowledgements}

This work was supported by a grant from Vega No. 2/0121/08. The work has been carried out in compliance with current laws governing genetic experimentation in the Slovak Republic. 


\section{References}

APICHAISATAIENCHOTE, B., ALTENBUCHNER, J., BUCHENAUER, H.: Isolation and identification of Streptomyces fradiae SU-1 from Thailand and protoplast transformation with the chitinase B gene from Nocardiopsis prasina OPC-131. Curr. Microbiol., 51, 2005, 116-121.

EL-GENDY, M.M.A., SHAABAN, M., EL-BONDKLY, A.M., SHAABAN, K.A.: Bioactive Benzopyrone Derivatives from New Recombinant Fusant of Marine Streptomyces. Appl. Biochem. Biotechnol., doi: 10.1007/s12010-008-8192-5.

FARKAŠOVSKÁ, J., GODÁNY, A., VLČEK, Č.: Identification and characterization of an endolysin encoded by the Streptomyces aureofaciens phage $\mu 1 / 6$. Folia Microbiol., 48, 2003, 737-744.

GARCIA-DOMINGUEZ, M., MARTIN, J.F., MAHRO, B., DEMAIN, A.L., LIRAS, P.: Efficient plasmid transformation of the $\beta$-lactam producer Streptomyces clavuligenes. App. Environ. Microbiol., 53, 1987, 1376-1381.

GODÁNY, A., NAZAROV, V., OKTAVCOVÁ, B., ŠEVČÍKOVÁ, B., KOTERCOVÁ, I.: Streptomyces aureofaciens strains as hosts for cloning of genes affecting antibiotic production. Biotechnol. Lett., 13, 1991, 471-476.

HOPWOOD, D.A., BIBB, M.J., CHATER, K.F., KIESER, T., BRUTON, C.J., KIESER, H.M., LYDIATE, D.J., SMITH, C.P., WARD, J.M., SCHREMPF, H.: In: Genetic Manipulation of Streptomyces: a Laboratory Manual. The John Innes Foundation, Norwich, 1985.

HOU, Y.-H., LI, F.-C., WANG, S.-J., QIN, S., WANG, Q.-F.: Intergenetic conjugation in holomycin-producing Streptomyces sp. Strain M095. Microbiol. Res., 163, 2008, 96-104.

IMADA, C., IKEMOTO, Y., KOBAYASHI, T., HAMADA, N., WATANABE, E.: Isolation and characterization of the interspecific fusants from Streptomycetes obtained using a liquid regeneration method. Fish. Sci., 68, 395-402.

KIESER T., BIBB M.J., BUTTNER M.J., CHATER K.F., HOPWOOD D.A.: Practical Streptomyces Genetics, 2nd edn., Norwich, UK: John Innes Foundation, 2000.

MATSUSHIMA P, BALTZ R.H.: Efficient plasmid transformation of Streptomyces ambofaciens and Streptomyces fradiae protoplasts. J. Bacteriol., 163, 1985, 180 185.

MATSUSHIMA, P., COX, K.L., BALTZ, R.H.: Highly transformable mutants of Streptomyces fradiae defective in several restriction systems. Mol. Gen. Genet., 206, 1987, 393-400.

MELlOULI, L., KARRAY-REBAI, I., SIOUD, S., AMEUR-MEHDI, R.B., NAILI, B., BEJAR, S.: Efficient transformation procedure of a newly isolated Streptomyces sp. TN58 strain producing antibacterial activities. Curr. Microbiol., 49, 2004, 400-406.

MUCHOVÁ, J., LACOVÁ, B., GODÁNY, A., ŠEVČÍKOVÁ, B.: Highly transformable mutants of Streptomyces aureofaciens containing restrictionmodification systems. J. Basic Microbiol., 31, 1991, 141- 147. 
NAZAROV, V., ŽATKOVIČ, P., GODÁNY, A.: New shuttle promoter-probe vectors for E. coli and Streptomycetes. Biotechnol. Lett., 12, 1990, 639-644.

OCHI, K.: Protoplast fusion permits high-frequency transfer of a Streptomyces determinant which mediates actinomycin synthesis. J. Bacteriol., 150, 1982, 592597.

PARANTHAMAN, S., DHARMALINGAM, K.: Intergeneric conjugation in Streptomyces peucetius and Streptomyces sp. Strain C5: Chromosomal Integration and expression of recombinant plasmids carrying the chic gene. Appl. Environ. Microbiol., 69, 2003, 84-91.

PIGAC, J., SCHREMPF, H.: A simple and rapid method of transformation of Streptomyces rimosus R6 and other Streptomycetes by electroporation. Appl. Environ. Microbiol., 61, 1995, 352-356.

RODICIO, M.R., MANZAL, M.B., HARDISSON, C.: Protoplast formation during spore germination in Streptomyces. Curr. Microbiol., 1, 1978, 89-92.

SHIRAHAMA, T., FURUMAI, T., OKANISHI, M.: A modified regeneration method for Streptomycete protoplasts. Agric. Biol. Chem., 45, 1981, 1271-1273.

VOEYKOVA, T., EMELYANOVA, L., TABAKOV, V., MKRTUMYAN, N.: Transfer of plasmid pTO1 from Escherichia coli to various representatives of the order Actinomycetales by intergeneric conjugation. FEMS Microbiol. Lett., 162, $1998,47-52$.

XU, B., JIN, Z., WANG, H., JIN, Q., JIN, X., CEN, P.: Evolution of Strptomyces pristinaespiralis for resistance and production of pristamycin by genome shuffling. Appl. Microbiol. Biotechnol., doi: 10.1007/s00253-008-1540-0.

YANG, S.-S., LEI, C.-M.: Formation and regeneration of protoplasts for protease production in Streptomyces rimosus. J. Microbiol. Immunol. Infect., 34, 2001, 816. 